\title{
PENGARUH BUMBU TERHADAP KADAR LOGAM BERAT KADMIUM (Cd) PADA UDANG VANNAME (Litopenaeus vannamei)
}

\author{
Gerhani Veronika ${ }^{1}$, Hening Widowati ${ }^{2}$, Widya Sartika Sulistiani ${ }^{3}$ \\ ${ }_{1,3}$ Pendidikan Biologi UM Metro, ${ }^{2}$ Pascasarjana UM Metro \\ E-mail: ${ }^{1 *}$ gerhaniveronica123@gmail.com, ${ }^{2}$ hwummetro@gmail.com, \\ ${ }^{3}$ widya.sulistiani@gmail.com
}

\begin{abstract}
Abstrak: Udang vaname (Litopenaeus vannamei) merupakan salah satu jenis hewan penyaring (filter feeder) yaitu pemakan partikel, materi organic, serta makhluk hidup yang ada di lingkungannya. Kadmium (Cd) mempunyai sifat toksisitas (kemampuan zat kimia yang menimbulkan kerusakan suatu organisme) dimana pada konsentrasi yang rendah sekalipun. Antioksidan adalah zat yang mampu memperlambat atau mencegah proses oksidasi. Antioksidan bekerja dengan cara mendonorkan satu elektronnya kepada senyawa yang bersifat oksidan/radikal bebas, sehingga aktivitas senyawa oksidan tersebut dapat dihambat. Antioksidan alami banyak ditemukan di lingkungan sekitar seperti, buahbuahan, sayuran, dan rempah-rempah indonesia seperti kunyit, jahe, cabe, bawang merah, bawang putih, dan lain-lain. Penggunaan bahan bahan yang mengandung antioksidan seperti rempah rempah dianggap mampu mengurangi efek toksisitas dari logam berat timbal. Tujuan dari penelitian ini adalah untuk mengetahui pengaruh penguunaan bumbu terhadap kadar logam berat cadmium pada udang vename. Penelitian menggunakan rancangan acak lengkap dengan 3 variasi perlakuan dan 1 kontrol. Analisis data menggunakan ANAVA Satu Arah. Hasil penelitian menunjukkan penggunaan bumbu pada olahan udang vanname mampu menurunkan kadar Cadmium $(\mathrm{Cd})$ dengan hasil terbaik pada perlakuan $\mathrm{C}$.
\end{abstract}

Kata Kunci : udang vanname (Litopenaeus vannamei); logam kadmium (Cd); antioksidan

\begin{abstract}
Abstrack: Vannamei shrimp (Litopenaeus vannamei) is one type of filter feeder, which eats every particles, organic matter, and living things in their environment. Cadmium $(C d)$ has toxicity properties (the ability of chemicals to cause damage to an organism) even at low concentrations. Antioxidants are substances that can slow down or prevent the oxidation process. Antioxidants work by donating one electron to compounds that are oxidants/free radicals, so that the activity of these oxidant compounds can be inhibited. Many natural antioxidants are found in the environment, such as fruits, vegetables, and Indonesian spices such as turmeric, ginger, chili, shallots, garlic, and others. The use of materials containing antioxidants such as spices is considered to be able to reduce the toxic effects of lead heavy metal. The purpose of this study was to determine the effect of the use of spices on the levels of heavy metal cadmium in vename shrimp. The study used a completely randomized design with 3 treatment variations and 1 control. Data analysis using One-Way ANOVA. The results showed that the use of spices in processed vannamei shrimp was able to reduce levels of Cadmium $(C d)$ with the best results in treatment $C$.
\end{abstract}

Keywords: vannamei shrimp (Litopenaeus vannamei); cadmium metal (Cd); antioxidant

How to Cite

Veronika, Gerhani, Hening Widowati, Widya Sartika Sulistiani. 2021. Pengaruh Bumbu Terhadap Kadar Logam Berat Kadmium (Cd) Pada Udang Vanname (Litopenaeus vannamei). BIOLOVA 3(1). 13-18. 


\section{Udang}

(Litopenaeus

vaname

vannamei)

merupakan salah satu hasil tambak dari masyarakat Pasir Sakti, Lampung. Udang sendiri merupakan salah satu jenis hewan penyaring (filter feeder) yang makan dengan cara menyaring segala yang ada diilingkungan hidupnya ke dalam mulut. Sehingga udang vanname lebih rentang terkontaminasi oleh logam berat seperti Kadmium (Cd). Terkontaminasinya Udang vaname yang hidup di laut oleh logam berat akan membahayakan manusia saat dikonsumsi. Walaupun efek yang diraskan tidak langsung, namun akan mengendap dan menyebabkan penyakit di kemudian hari, efek jangka pedeknya dapat menyebabkan keracunan. (Susanti, 2021).

Kadmium (Cd) merupakan unsur logam berat yang dapat ditemukan bebas dilingkungan sekitar,sebagai produk samping dari penambangan, transportasi, industri dan lain-lain. Khususnya dilingkungan perairan dimana Kadmium (Cd) memiliki toksisitas (kemampuan zat kimia yang menimbulkan kerusakan suatu organisme) dimana pada konsentrasi yang rendah sekalipun.

Konsumsi Cadmium yang melebihi batas ambang normal akan mempengaruhi kesehatan masyarakat. Menurut BPOM Indonesia (2018) "batas maksimum Cd pada Ikan dan Produk Perikanan Termasuk Moluska, Krustase, dan Ekinodermata serta Amfibi dan Reptil adalah 0,10 mg/kg”. Ketika mengkonsumsi udang vanname tidak memperhatikan ambang batas konsumsi $\mathrm{Cd}$ dan dampaknya maka dapat membahayakan bagi kesehatan tubuh maka perlu diperhatikan cara pengolahan udang vanname agar kadar batas logam berat tidak di atas batas maksium. Keracunan $\mathrm{Cd}$ dapat menyebabkan tekanan darah tinggi, kerusakan jaringan testicular, kerusakan ginjal dan sel-sel darah merah. Itai-itai merupakan salah satu kerapuhan tulang karena $C d$. Selain itu $C d$ dapat menyebabkan gangguan pertumbuhan, reproduksi, hipertensi, teratogenesis bahkan kanker. Widowati (2011:167).

Mengingat bahaya konsumsi udang yang telah terkontaminasi $\mathrm{Cd}$ maka perlu memperhatikan cara pengolahan udang. Upaya dalam menurunkan kadar $\mathrm{Cd}$ pada daging udang telah dilakukan oleh Anggraeni (2021) dengan merendam daging ke dalam asam buah alami untuk menurunkan kadar Cadmium pada daging udang. Hasil penelitian menunjukkan dengan direndamnya daging udang ke dalam larutan asam buah alami, mampu menurunkan kadar Cadmium dalam udang, dengan perlakuan terbaik pada perendaman dengan jeruk nipis. Indonesia adalah Negara yang kaya akan hasil alam juga rempah rempahnya yang dapat dijadikan bumbu untuk masakan. Pemanfaatan bumbu dalam pengolahan makanan merupakan warisan budaya leluhur Indonesia. Bumbu biasanya digunakan sebagai bahan memberikan rasa atau menambahkan rasa dan aroma dari sebuah masakan. Hampir seluruh masakan Indonesia kaya dengan bumbu seperti : bawang merah, bawang putih, kemiri, cabai, kunyit, kelapa, kencur, jahe dan lainlain. Bumbu mengandung kaya antioksidan yang berguna menangkal radikal bebas yang ada didalam daging udang vananme.

Antioksidan adalah zat yang 
mampu memperlambat atau mencegah proses oksidasi. Antioksidan bekerja dengan cara mendonorkan satu elektronnya kepada senyawa yang bersifat oksidan/radikal bebas, sehingga aktivitas senyawa oksidan tersebut dapat dihambat. Antioksidan alami banyak ditemukan di lingkungan sekitar seperti, buah-buahan, sayuran, dan rempah-rempah indonesia seperti kunyit, jahe, cabe, bawang merah, bawang putih, dan lain-lain (Helmalia, dkk. 2019).

Penggunaan bumbu dalam rangka pengolahan daging udang dirasa mampu menurunkan kadar $\mathrm{Cd}$ pada daging udang. Sehingga penelitian bertujuan untuk mengetahui pengaruh Bumbu alami terhadap Penurunan Kadar kadmium $(\mathrm{Cd})$.

\section{METODE PENELITIAN}

Penelitian menggunakan rancangan acak lengkap dengan 3 variasi perlakuan dan 1 kontrol. Analisis data menggunakan ANAVA Satu Arah. Sampel udang yang digunakan didapatkan dari tambak intensif jauh mangrove sampel diambil sebanyak $1 \mathrm{~kg}$ untuk masingmasing ulangan sebanyak 400 gram.

Alat yang digunakan adalah: pisau, wajan, presto, ember, baskom, nampan, peniris, timbangan, sutil, gunting, talenan, plastik, steroform, kertas label, botol sampel, spidol atau pena.

Bahan yang digunakan dalam penelitian yaitu: udang vanname sebnyak 1,6 kg, Bawang Merah $1 \mathrm{~kg}$, Bawang Putih $1 / 2 \mathrm{Kg}$, jeruk nipis $1 \mathrm{~kg}$ Cabe Merah $1 / 2$ $\mathrm{Kg}$, Cabe Rawit Hijau 1/4 Kg,
Cabe Rawit Merah $1 / 4 \mathrm{Kg}$, Tomat $1 / 2$ $\mathrm{Kg}$, Jahe $1 / 4 \mathrm{Kg}$, Kunyit $\quad 1 / 4 \mathrm{Kg}$, Daun Salam 1 Ikat, Sereh 2 Ikat, Daun Jeruk, Daun Pandan 1 Ikat, Daun Kunyit 2 Ikat, Daun Bawang 3 Ikat, Daun Kemangi 3 Ikat, Ketumbar, Kemiri, Garam, Gula 1/2 Kg dan Natrium Benzoat.

Tahapan yang pertama dilakukan adalah Menentukan tempat pengambilan sampel, penelitian ini lokasi pengambilan sampel di tambak intensif jauh mangrove Pasir Sakti Lampung Timur. Kemudian Menentukan ukuran sampel yang akan diambil dari keseluruhan anggota, dalam penelitian ini sampel udang vaname diambil sebanyak 1.600 gram untuk sampel yang digunakan untuk perlakuan ke 1, 2, 3 dan 4 masing-masing 400 gram. Selanjutnya membersihkan dan menimbang sampel, setalh itu diolah dengan 3 variasi bumbu (Bumbu A, Bumbu B, dan Bumbu C).

\section{HASIL PENELITIAN DAN PEMBAHASAN}

\section{Hasil Penelitian}

Berdasarkan penelitian yang telah dilakukan, maka didapatkan hasil penelitian sebagai berikut :

Tabel 1. Kadar Logam Kadmium (Cd) pada Daging Udang Vanname $(\mu \mathrm{g} / \mathrm{kg})$

Kadar Logam Cd pada setiap Perlakuan

$\begin{array}{ccccc}\text { Ulangan } & \text { Kontrol } & \begin{array}{c}\text { Bumbu } \\ \text { A }\end{array} & \begin{array}{c}\text { Bumbu } \\ \text { B }\end{array} & \begin{array}{c}\text { Bumbu } \\ \text { C }\end{array} \\ \text { U1 } & 248,819 & 170,902 & 158,820 & 137,249 \\ \text { U2 } & 254,628 & 176,521 & 162,787 & 141,458 \\ \text { U3 } & 209,968 & 137,605 & 112,150 & 100,447 \\ \text { U4 } & 215,402 & 141,148 & 116,012 & 106,246 \\ \text { U5 } & 229,472 & 143,412 & 129,787 & 102,279 \\ \text { U6 } & 225,473 & 141,486 & 127,603 & 104,293 \\ \text { U7 } & 204,144 & 117,965 & 102,320 & 102,442 \\ \text { U8 } & 207,971 & 121,798 & 106,331 & 104,377 \\ \text { Jumlah } & 224,485 & 143,855 & 126,976 & 112,349 \\ \text { Rata- } & & & & \\ \text { rata } & & & & \end{array}$


Berdasarkan data Tabel 1 diatas maka dapat dideskripsikan bahwa kadar kadmium (Cd) pada daging udang vanname memiliki kadar kadmium $(\mathrm{Cd})$ yang berbeda pada tiap perlakuan. Perlakuan kontrol memilikikadar cadmium $(\mathrm{Cd})$ rata-rata 224,485 ppb. Perlakuan dengan Bumbu A pada udang vanname memiliki rata-rata kadar kadmium sebesar 143,855 ppb. Perlakuan dengan Bumbu B pada udang vanname mengalami penurunan sebesar sebesar 126,976 ppb dibandingkan kontrol. Perlakuan dengan Bumbu $\mathrm{C}$ pada udang vanname memiliki rata-rata kadar kadmium yang lebih kecil dari kontrol yaitu sebesar 112,349 ppb.

\section{PEMBAHASAN}

\section{Pengaruh Bumbu terhadap Kadar Logam Berat Kadmium (Cd) pada Udang Vanname (Litopenaeus vannamei)}

Berdasarkan hasil penelitian yang telah dilakukan dapat dibuktikan bahwa kandungan $\mathrm{Cd}$ pada udang vanname (Litopenaeus vannamei) yang terdapat pada tambak intesif jauh mangrove adalah 224,485 ppb.

Menurut BPOM Indonesia (2018) "batas maksimum Cd pada Ikan dan Produk Perikanan Termasuk Moluska, Krustase, dan Ekinodermata serta Amfibi dan Reptil adalah $0,10 \quad \mathrm{mg} / \mathrm{kg}$. Bersumber dari pernyataan yang ditetapkan oleh BPOM Indonesia diketahui bahwa kandungan $\mathrm{Cd}$ pada udang vanname ini masih tidak melebihi ambang batas konsumsi, karena 224,485 ppb setara dengan $0,00000000224 \mathrm{mg} / \mathrm{kg}$ apabila dikonsumsi terus menerus akan namun akan mengganggu kesehatan.

Perlakuan pertama dengan menggunakan Bumbu A turun menjadi 143,855 ppb dari rata-rata ulangan. Bumbu A (5 jenis bumbu) menggunakan rempah-rempah seperti cabe, bawang merah, tomat, daun kemangi, dan air perasan jeruk nipis.

Perlakuan kedua dengan menggunakan Bumbu B turun menjadi $126,976 \mathrm{ppb}$ dari rata-rata ulangan. Bumbu B (10 jenis bumbu) menggunakan rempah-rempah seperti cabe, bawang putih, bawang merah, jahe, tomat, daun bawang, daun kemangi, daun salam, serai, dan air perasan jeruk nipis.

Perlakuan ketiga dengan menggunakan Bumbu B turun menjadi 112,349 ppb dari rata-rata ulangan. Bumbu C (13 jenis bumbu) menggunakan rempah-rempah seperti cabe, bawang putih, bawang merah, jahe, kunyit, kemiri, tomat, daun bawang, daun kemangi, daun jeruk, daun pandan, serai, dan air perasan jeruk nipis.

Penurunan kadar Kadmium (Cd) pada setiap perlakuan berbeda-beda disebabkan oleh adanya kandungan antioksidan alami yang berbeda-beda karena jumlah jenis-jenis bumbu yang digunakan. Antioksidan merupakan zat yang mampu memperlambat atau mencegah proses oksidasi (Malangngi, 2012).

Antioksidan berfungsi untuk menghentikan atau memutuskan reaksi berantai dari radikal bebas dengan cara mendonorkan satu elektronnya kepada senyawa yang bersifat oksidan sehingga aktivitas senyawa oksidan tersebut bisa terhambat atau lebih stabil.

Salah satu sumber antioksidan alami terdapat dalam tanaman adalah Bawang putih memiliki kandungan 
Organosulfur dan senyawa fenolik sebagai antioksidan memegang peranan sangat penting untuk mencegah kerusakan sel dan organ dari proses oksidasi. Senyawa fenolik dari bawang putih memiliki kelompok berjumlah satu atau lebih yaitu sebagai donor proton hidrogen dan menetralisir radikal bebas (Prasonto, dkk. 2017).

Senyawa flavonoid, fenolik, dan tanin merupakan senyawa yang bertanggung jawab terhadap aktivitas antioksidan. Aktivitas antioksidan pada ketiga senyawa tersebut karena senyawa-senyawa fenol, yaitu senyawa yang memiliki gugus $-\mathrm{OH}$ yang terikat pada karbon cincin aromatik. Senyawa fenol ini mempunyai kemampuan untuk mendonorkan atom hidrogen sehingga radikal dapat tereduksi menjadi bentuk yang lebih stabil (Prasonto, dkk. 2017).

Flavonoid merupakan senyawa polifenol yang dihasilkan dari metabolisme sekunder pada tanaman. Quercetin ditemukan di banyak buah dan sayuran tapi juga banyak terdapat pada bawang merah, apel merah, anggur merah, teh, cranberry, kangkung, paprika dan brokoli (Arifin 2018).

Kemferol yang termasuk golongan flavonoid adalah senyawa organik bahan alam dan merupakan senyawa polifenol (senyawa fenolik yang mempunyai lebih dari satu gugus hidroksil) (Fauziah, dkk. 2017). Adapun mekanisme pengikatan logam oleh senyawa flavonoid yakni senyawa kemferol golongan flavonol :
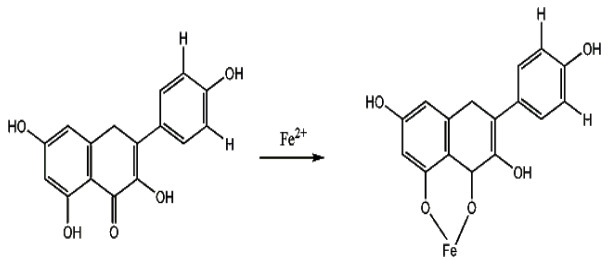

Gambar 1. Mekanisme Pengikatan
Logam oleh Flavonoid

Sumber : (Fauziah, dkk. 2017).

Pembentukan radikal $\mathrm{OH}$ ini dapat dibatasi dengan cara mengurangi katalis reaksi oksidasi yakni ion logam $\mathrm{Cd} 2+$. Antioksidan chelator yaitu antioksidan yang bekerja dengan cara mengikat logam yang berperan sebagai katalis reaksi oksidasi untuk mengurangi jumlah ion logam $\mathrm{Cd} 2+$ sehingga dapat membatasi pembentukan radikal hidroksil dari reaksi logam dengan hidrogen peroksida, maka senyawa antioksidan mampu mengikat $\mathrm{Pb} 2+$ dan akan membentuk senyawa kompleks yang lebih stabil.

\section{Jenis Bumbu yang Memberikan Pengaruh Penurunan Paling Baik}

Berdasarkan penelitian yang telah dilakukan dapat diketahui bahwa semua jenis buah yang digunakan dapat memberikan pengaruh penurunan.

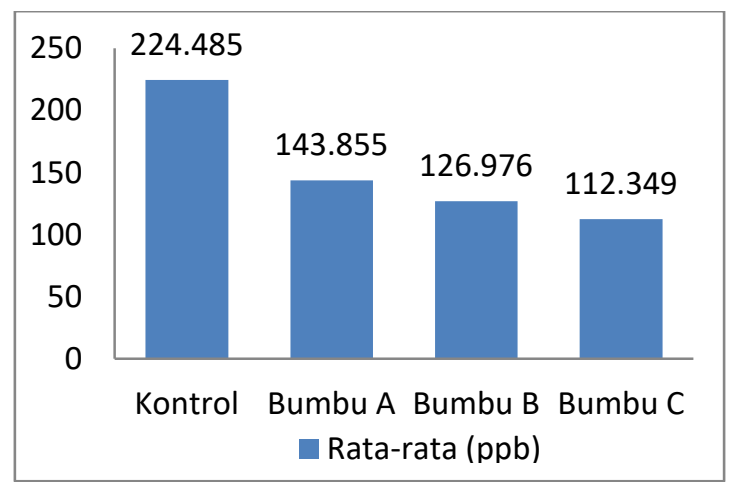

Berdasarkan Gambar 2 di atas dapat diketahui bahwa pada udang tambak intensif jauh mengrove Perlakuan Bumbu C menurunkan kadar logam berat Kadmium $(\mathrm{Cd})$ paling baik pertama yaitu turun sebesar 112,349 ppb. Perlakuan Bumbu B kedua dengan penurunan 126,976 ppb. Perlakuan Bumbu A menghasilkan penurunan terkecil yaitu turun sebesar 143,855 ppb. dengan penurunan sebesar $143,855 \mathrm{ppb}$.

\section{KESIMPULAN}

Berdasarkan dari hasil penelitian yang 
telah dilakukan dapat disimpulkan bahwa perlakuan atau variasi bumbu yang digunakan mempenagruhi kadar logam berat Kadmium (Cd) pada daging udang vanname (Litopenaeus vannamei) dengan menggunakan jenis bumbu alami yang kaya antioksidan. Perlakuan Bumbu C (13 jenis bumbu) menurunkan bnayak kadar logam berat Kadmium. Bumbu $\mathrm{C}$ menggunakan bumbu seperti cabe, bawang putih, bawang merah, jahe, kunyit, kemiri, tomat, daun bawang, daun kemangi, daun jeruk, daun pandan, serai, dan air perasan jeruk nipis.

\section{SARAN}

Berdasarkan penelitian yang telah dilakukan yaitu perlunya penelitian lebih lanjut mengenai mekanisme antioksidan dari berbgai macam bumbu alami atau lokal dalam menurunkan kadar logam berat lainnya.

\section{DAFTAR PUSTAKA}

Anggraini, B., Widowati, H., \& Sulistyani, W. S. (2021). Pengaruh Perendaman Jenis Buah Terhadap Penurunan Kadar Kadmium (Cd) Pada Udang Vanname (Litopenaeus Vannamei) Tambak Intensif Dekat Dan Jauh Mangrove. BIOLOVA, 2(2), 151-163.

Arifin, B., \& Ibrahim, S. (2018). Struktur, bioaktivitas dan antioksidan flavonoid. Jurnal Zarah, 6(1), 21-29.

Badan Pengawas Obat Dan Makanan Nomor 5 Tahun 2018 Tentang Batas Maksimum Cemaran Logam Berat dalam Pangan Olahan. 12 Sepetember 2021. Berita Negara Republik Indonesia Tahun 2018 Nomor 673.
Jakarta.

Fauziah, S., dan Syahmani .2011. Potensi Antioksidan Kulit Batang Tumbuhan Ketapang (Terminalia catappa Linn.). Jurnal Inovasi Pendidikan Sains, 2(1), h. 69-80.

Helmalia, A. W., Putrid, dan Dirpan, A. 2019. Potensi Rempah-Rempah Tradisional sebagai Sumber Antioksidan Alami untuk Bahan Baku Pangan Fungsional). Jurnal Canrea, 2(1), h. 26-31.

Malangngi, L., Sangi, M., \& Paendong, J. (2012). Penentuan kandungan tanin dan uji aktivitas antioksidan ekstrak biji buah alpukat (Persea americana Mill.). Jurnal Mipa, 1(1), 5-10.

Prasonto, D., Riyanti, E., dan Gartika, M. 2017. Uji Aktivitas Antioksidan Ekstrak Bawang Putih (Allium sativum). Jurnal Odonto Dental, 4(2), h. 122128.

Susilawati, D. (2021). Pengaruh Variasi Perendaman Udang Vaname (Litopenaeus Vannamei) Dalam Asam Buah Alami Terhadap Penurunan Kadar Timbal $(\mathrm{Pb})$ Di Tambak Tradisional Pasir Sakti Lampung Timur. BIOLOVA, 2(2), 134143.

Widowati, H. 2011. Pengaruh Logam Berat $\quad \mathrm{Cd}, \mathrm{Pb}$ terhadap Perubahan Warna Batang dan Daun Sayuran. Jurnal ElHayah, 1(4), h. 167-173. 